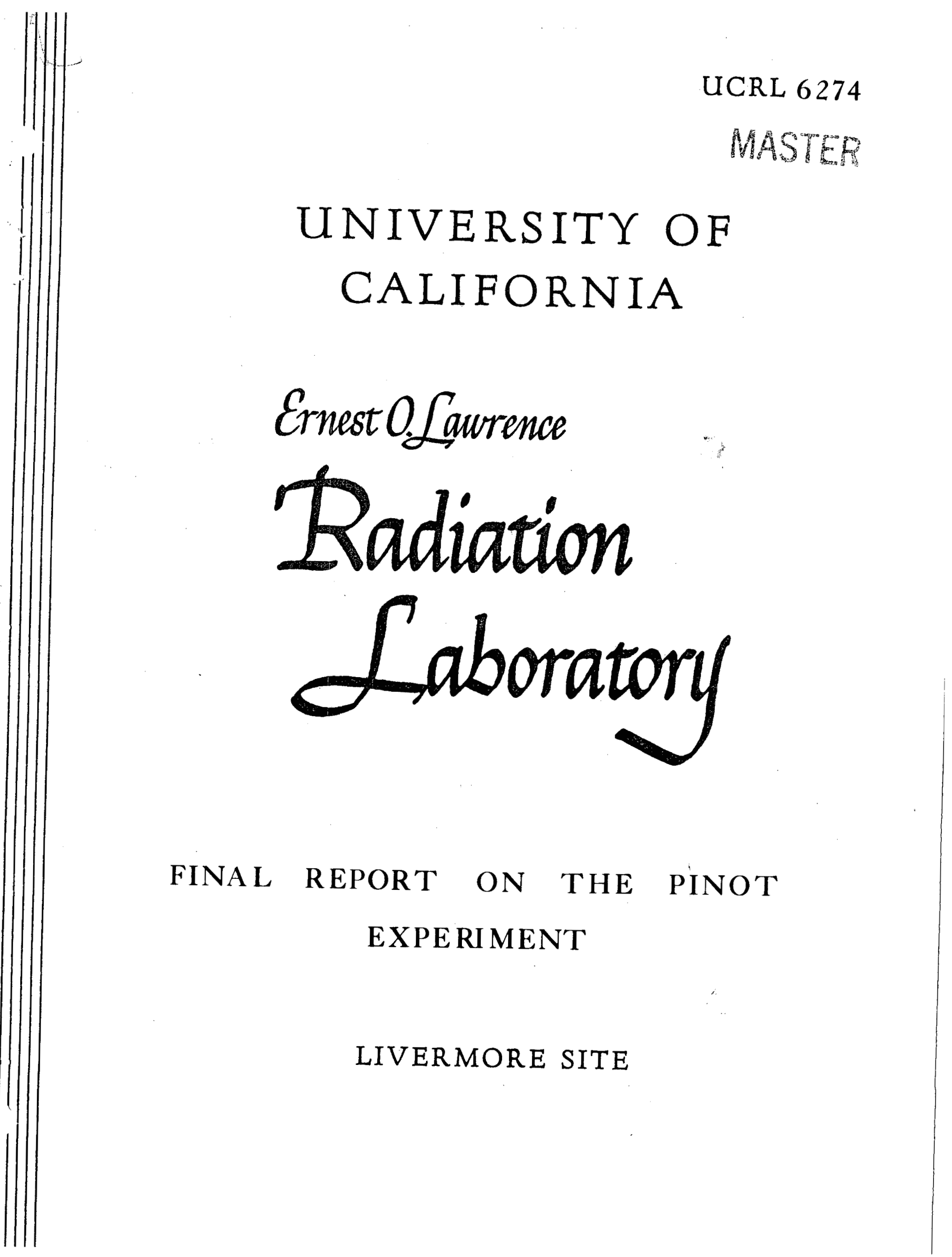




\section{DISCLAIMER}

This report was prepared as an account of work sponsored by an agency of the United States Government. Neither the United States Government nor any agency Thereof, nor any of their employees, makes any warranty, express or implied, or assumes any legal liability or responsibility for the accuracy, completeness, or usefulness of any information, apparatus, product, or process disclosed, or represents that its use would not infringe privately owned rights. Reference herein to any specific commercial product, process, or service by trade name, trademark, manufacturer, or otherwise does not necessarily constitute or imply its endorsement, recommendation, or favoring by the United States Government or any agency thereof. The views and opinions of authors expressed herein do not necessarily state or reflect those of the United States Government or any agency thereof. 


\section{DISCLAIMER}

Portions of this document may be illegible in electronic image products. Images are produced from the best available original document. 
UCR L- 6274

Nuclear Explosions -

Peaceful Applications, UC-3 5

TID-4500 (16th Ed.)

\author{
UNIVERSITY OF CALIFORNIA \\ Lawrence Radiation Laboratory \\ Livermore, California \\ Contract No. W-7405-eng-48
}

FINAL REPOR T ON THE PINOT EXPERIMENT

\author{
Frank L. Adelman \\ Clifford M. Bacigalupi \\ Floyd F. Momyer
}

December 27, 1960 
Printed in USA. Price \$.50. Available from the Office of Technical Services, Department of Commerce, Wa shington 25, D. C. 


\title{
FINAL REPORT ON THE PINOT EXPERIMENT
}

\author{
F. L. Adelman, C. M. Bacigalupi, and F. F. Momyer
}

Lawrence Radiation Laboratory, University of California

Livermore, California

December 27, 1960

\begin{abstract}
Pinot is the code name for a small chemical explosive experiment carried out in August, 1960 in a mine controlled by the U. S. Bureau of Mines at the Anvil Points Experimental Oil Shale Station near Rifle, Colo. The project was designed to provide some indication of the extent to which gases from a confined underground explosion in oil shale would migrate parallel to the bedding planes.

At 0800 on August 2, 1960, 946 lb of nitromethane was fired in shot hole No. 1. There was no visible damage to the mine adit or to any structure associated with the workings. Gas samples collected from sampling holes near the shot hole were analyzed for $\mathrm{Kr}^{85}$, which had been included with the nitromethane as a tracer. It appears that the $\mathrm{Kr}{ }^{85}$ concentration in the samples out to $50 \mathrm{ft}$ was more or less independent of space and time between +2 and +50 hours. Relatively little $\mathrm{Kr}^{85}$ was detected at $125 \mathrm{ft}$ and none beyond. About $(20 \pm 10) \%$ of the $\mathrm{Kr}^{85}$ escaped into the adit.

The results of the Pinot experiment cannot be extrapolated quantitatively to the case of a nuclear explosion in oil shale. Even if the structure at the Pinot site is typical of oil shale, the generation of a smaller quantity of non condensable gases per unit energy in a nuclear explosion (as compared with a chemical explosion), the shorter time scale of the energy release, and the higher temperatures and pressures encountered will all have a definite influence on the effective containment distance. One can conclude, however, that, if the medium at the site of a potential nuclear experiment is similar to that at Pinot, the radioactive gases will not travel preferentially in direction parallel to the bedding planes, but rather will tend to expand more or less spherically from the shot point. In other words, an explosion in oil shale designed not to vent in a direction perpendicular to the bedding planes will be just as tight parallel to the bedding planes.
\end{abstract}


UCRL- 6274

$-4-$

$\ominus$

BLANK PAGE 


\title{
FIN $\leadsto$ L REPORT ON THE PINOT EXPERIMENT
}

\author{
F. L. Adelman, C. M. Bacigalupi, and F. F. Momyer \\ Lawrence Radiation Laboratory, University of California \\ Livermore, California
}

\section{INTRODUCTION}

Pinot is the code name for a small chemical explosive experiment carried out in August, 1960 in a mine controlled by the U. S. Bureau of Mines at the Anvil Points Experimental Oil Shale Station near Rifle, Colo. The project was designed to provide some indication of the extent to which gases from a confined underground explosion in oil shale would migrate parallel to the bedding planes. This question has come up several times in the past, with the argument that, since the bedding planes are planes of weakness, the pressure generated in a nuclear explosion, both directly and from the decomposition of $\mathrm{CaCO}_{3}$ and organic matter present in the oil shale, will force apart the layers and propel radioactive gases along these planes to the atmosphere. While the difference in gas movement parallel to and normal to the bedding planes was not expected to be at all large, it was felt that data on this effect are an essential part of the continuing study of the problems associated with the recovery of petroleum products from oil shale using nuclear explosive energy. Information on the containment of chemical explosions will be extremely useful when and if the design of a nuclear explosion in oil shale is authorized.

The program as designed consisted of two detonations of nitromethane $\left(\mathrm{CH}_{3} \mathrm{NO}_{2}\right)$, a liquid whose explosive properties are similar to those of TNT. The first of these was approximately $1000 \mathrm{lb}$ of explosive, containing about 1 curie of $\mathrm{Kr}^{85}$ as a tracer. The explosive device was grouted into the formation at a depth of $126 \mathrm{ft}$ below the mine floor. The other detonation was to be $5000 \mathrm{lb}$ of nitromethane in an analogous arrangement. Around each shot hole there was an array of 6 sampling holes located at ranges from 20 to $125 \mathrm{ft}$ from ground zero. From analysis of the distribution of $\mathrm{Kr}^{85}$, it was expected that useful information would be obtainedabout the movement of the explosively produced gases parallel to the bedding planes. This would assist greatly in the design of a nuclear experiment. 


\section{GEOLOGY OF THE SITE}

A plan view of the Anvil Points Oil Shale Mine is shown in Fig. 1, and more detailed views of the adit in which the experiment was conducted are given in Figs. 2 and 3.

In order to understand the geological environment of the Pinot experiment, an NX core hole was drilled about $120 \mathrm{ft}$ down below the floor of the adit. These cores, taken at semple hole 2.6, were compared with data from the U. S. Bureau of Mines core hole "A" (see Fig. 1). As one can see from Fig. 3, the materials of importance at the shot and sample locations are mainly lean to medium oil shale and marlstone. A lithologic description of the cores obtained from hole 2.6 is as follows:

From Elev. To Elev. 8188.8

8188.8

8186.8

8184.3

8177.8

8175.8

8175.8

8173.3

8173.3

8167.8

8167.8

8165.0

8165.0

8164.3

8149.9

8149.9

8149.1

8164.3
Description

Collar elevation.

Oil shale, lean to medium, brown to grey well defined bedding. Good banding. Rare tuff stringers in upper part. Represented by 8-in. core.

Oil shale, lean, tan to grey, well defined bedding. Fair banding. 4-in. grey tuff at 8186.7 , 1 -in. rusty tuff at $8186.0 \mathrm{ft}$.

Marlstone, tan to buff, poorly defined bedding. Common streaks of lean oil shale. Rare pyrite, vertical fractures $8186.3-8182.8 \mathrm{ft}$ and $8179.3-$ $8177.0 \mathrm{ft} 2$-in. medium oil shale at bottom.

Marlstone, tan to buff, massive. Rare pyrite.

Oil shale, very lean, light brown to light grey, poorly defined bedding. Rare pyrite streaks.

Marlstone, tan, massive to faintly bedded.

Silty in part.

Marlstone, silty, light grey to tan massive to poorly defined bedding.

Siltstone, tuffaceous, rusty, massive. 1-in. grey tuff bed in middle. Grades into silty marlstone.

Marlstone, silty, tan to light grey. Massive to faintly bedded. $0.6 \mathrm{ft}$ rusty zone at $8155.4 \mathrm{ft}$. 1 -in. grey tuff at $8155.1 \mathrm{ft}$. Rare pyrite streaks. Siltstone, tuffaceous, grey to rusty, massive. Rare pyrite. (continued) 


\begin{tabular}{|c|c|c|}
\hline From Elev. & To. Elev. & Description \\
\hline 8149.1 & 8141.8 & $\begin{array}{l}\text { Sandstone, rusty, fine-grained, silica cemented } \\
\text { in part. Rare silty zones. }\end{array}$ \\
\hline 8141.8 & 8139.4 & Siltstone, light grey, massive. \\
\hline 8139.4 & 8137.4 & $\begin{array}{l}\text { Sandstone, rusty, fine-grained, porous, contains } \\
\text { water. }\end{array}$ \\
\hline 8137.4 & 8135.9 & Siltstone, tuffaceous grey, massive. \\
\hline 8135.9 & 8134.6 & Sandstone, rusty, as in $8139.4 \mathrm{ft}-8137.4 \mathrm{ft}$. \\
\hline 8134.6 & 8101.5 & $\begin{array}{l}\text { Siltstone, grey to tan, poorly defined bedding. } \\
\text { Changing to marlstone in lower part. Common } \\
\text { pyrite stringers. }\end{array}$ \\
\hline 8101.5 & 8098.0 & $\begin{array}{l}\text { Marlstone, tan to grey, poor to well defined } \\
\text { bedding. Rare bands of oil shale at } 8101.5 \mathrm{ft} \\
\text { to } 8100.3 \mathrm{ft} \text {. }\end{array}$ \\
\hline 8098.0 & 8095.6 & $\begin{array}{l}\text { Oil shale, medium, dark brown, massive to } \\
\text { poorly defined bedding. Vertical fracture in } \\
\text { bottom } 14 \text { in. }\end{array}$ \\
\hline 8095.6 & 8092.1 & $\begin{array}{l}\text { Oil shale, lean to medium, brown to tan, well- } \\
\text { defined bedding, excellent banding. Rare pyrite } \\
\text { flakes. }\end{array}$ \\
\hline 8092.1 & 8089.6 & $\begin{array}{l}\text { Oil shale, medium, dark brown, massive to } \\
\text { faintly bedded. 1-in. grey tuff beds at } 8091.6 \mathrm{ft} \\
\text { and } 8089.7 \mathrm{ft} \text {. }\end{array}$ \\
\hline 8089.6 & 8086.4 & $\begin{array}{l}\text { Oil shale, lean to medium, brown to tan well } \\
\text { defined bedding. Common pyrite. I-in. tan } \\
\text { tuff at } 8089.0 \text { and } 2 \text {-in. grey hard tuff at } \\
8086.6 \mathrm{ft} \text {. }\end{array}$ \\
\hline 8086.4 & 8084.9 & $\begin{array}{l}\text { Oil shale, medium, brown to grey, well defined } \\
\text { bedding. Abundant pyrite flakes. }\end{array}$ \\
\hline 8084.9 & 8080.8 & $\begin{array}{l}\text { Marlstone, tan to brown, well defined bedding. } \\
\text { Rare bands of oil shale. }\end{array}$ \\
\hline 8080.8 & 8076.3 & $\begin{array}{l}\text { Oil shale, very lean, grey to brown, well defined } \\
\text { bedding, excellent banding. }\end{array}$ \\
\hline 8076.3 & 8075.0 & $\begin{array}{l}\text { Oil shale, medium, dark brown, poorly defined } \\
\text { bedding. }\end{array}$ \\
\hline 8075.0 & 8069.8 & $\begin{array}{l}\text { Oil shale, lean, brown to grey, well defined } \\
\text { bedding, excellent banding. Rare tuff stringers } \\
\text { and pyrite flakes. } 1 / 4-i n \text {. grey tuff at } 8072.8 \mathrm{ft} \text {. }\end{array}$ \\
\hline 8069.8 & & Bottom of hole. \\
\hline
\end{tabular}




\section{EXPERIMENTAL ARRANGEMENT}

The 1000-1b shot hole, which is shown in Fig. 4, was 10 in. in diameter and was reamed out to $20 \mathrm{in.}$ at the level of the explosion. The top of the nitromethane charge was $126 \mathrm{ft}$ below the floor of the adit and $610 \mathrm{ft}$ below the surface of the mesa slope. A picture of the explosive container appears in Fig. 5. The device package consisted, basically, of two booster blocks of Composition B enclosed in a polyethylene bag, a thin-walled stainless steel canister containing 1 curie of $\mathrm{Kr}^{85}$, and an outer polyethylene bag to hold the nitromethane. It was lowered into the reamed section and expanded to its full diameter by pouring nitromethane through an access tube. The hole was then grouted back to the floor of the adit. Each booster block was detonated by sending an electrical impulse to two pairs of blasting caps, each pair of which ignited a short length of primacord, which in turn set off a tetryl pellet recessed into the block. The energy generated in one booster block was sufficient to assure detonation of the nitromethane.

The six sampling holes associated with the first shot were $3-1 / 8$ in. in diameter and contained a 1/2-in. gas sampling pipe and a 3/4-in. pipe through which accumulated water could be removed. Each hole had one open section approximately $20 \mathrm{ft}$ in length; in holes 1.2 and 1.4 the open sections were about $20 \mathrm{ft}$ above the shot point, while in the other holes the open sections were more or less at the shot level. The characteristics of these holes are given in Table 1 . The arrangement for the 5000-1b shot was quite similar, except for the size of the device and the underreamed section of the shot hole.

\section{EXPERIMENTAL PROCEDURE AND OBSERVATIONS}

A few days before the scheduled detonation of the first shot it became evident that there was underground communication between the various holes associated with shot hole No. 1. ${ }^{*}$ This fact suggested strongly that $\mathrm{Kr}{ }^{85}$

\footnotetext{
* During the drilling of the shot and sample holes, circulation was lost at one or more levels in most of the holes. While this observation proved that there were underground voids in the oil shale, it shed no light on the question of connectivity. It was believed that the voids were not connected, until tests with injected air proved otherwise.
} 
Table I. Project Pinot Sample Hole Data.

\begin{tabular}{|c|c|c|c|c|c|c|}
\hline $\begin{array}{l}\text { Sample } \\
\text { Hole } \\
\text { No. }\end{array}$ & $\begin{array}{l}\text { Collar } \\
\text { station } \\
\text { (ft) }\end{array}$ & $\begin{array}{l}\text { Collar } \\
\text { elevation } \\
\quad(f t)\end{array}$ & $\begin{array}{l}\text { Bottom bearing } \\
\text { and distance } \\
\text { from collar } \\
\text { (ft) }\end{array}$ & $\begin{array}{c}\text { Bottom } \\
\text { elevation } \\
(f t)\end{array}$ & $\begin{array}{l}\text { Packer } \\
\text { elevation } \\
\text { ( } f t)\end{array}$ & $\begin{array}{l}\text { Horizontal } \\
\text { distance from } \\
\text { bottom of } \\
\text { Sample Hole to } \\
\text { No. I shot } \\
\text { chamber (ft) }\end{array}$ \\
\hline 1.1 & $5+88.4$ & 8206.3 & $\mathrm{~N} 67^{\circ} \mathrm{E} ; 1.2$ & 8073 & 8089 & 34.6 \\
\hline 1.2 & $5+34.5$ & 8203.4 & $\mathrm{~N} 82^{\circ} \mathrm{E}, 0.9$ & 8094 & 8114 & 20.2 \\
\hline 1.3 & $5+19.6$ & 8202.8 & $\mathrm{~N} 43^{\circ} \mathrm{E}, 0.9$ & 8070 & 8089 & 34.6 \\
\hline 1.4 & $5+04.5$ & 8201.1 & $\mathrm{~N} 38^{\circ} \mathrm{E}, 0.5$ & 8093 & 8113 & 49.9 \\
\hline 1. 5 & $4+79.5$ & 8199.8 & $\mathrm{~N} 75^{\circ} \mathrm{E}, 0.2$ & 8070 & 8089 & 75.2 \\
\hline 1.6 & $4+29.5$ & 8198.5 & $S 76^{\circ} \mathrm{E}, \quad 0.8$ & 8070 & 8089 & 125.5 \\
\hline 2.1 & $3+73.0$ & 8193.8 & $\mathrm{~N} 73^{\circ} \mathrm{E} ; 0.9$ & 8070 & 8090 & 181.7 \\
\hline 2.2 & $3+17.0$ & 8192.5 & $\mathrm{~N} 13^{\circ} \mathrm{W}, 2.5$ & 8087 & 8107 & 235.3 \\
\hline 2.3 & $3+02.0$ & 8191.7 & East, $\quad 0.1$ & 8070 & 8090 & 252.8 \\
\hline 2.4 & $2+87.0$ & 8191.3 & $\mathrm{~N} 29^{\circ} \mathrm{E}, 0.8$ & 8080 & 8100 & 267.4 \\
\hline 2.5 & $2+62.0$ & 8189.7 & $\mathrm{~N} 88^{\circ} \mathrm{E}, 0.9$ & 8070 & 8090 & 292.8 \\
\hline 2.6 & $2+12.0$ & 8188.5 & $\mathrm{~N} 57^{\circ} \mathrm{W}, 0.9$ & 8070 & 8090 & 342.3 \\
\hline
\end{tabular}

* Diameter of holes was 3-1/8 in. 
would travel significant distances through fractures and crevices after detonation; nevertheless, it was decided to proceed with the experiment, as the data to be gained would be valuable. One hour before the shot the water which had accumulated in. 5 of the 6 sampling holes was blown out. (Hole No. 1.5, at a distance of $75 \mathrm{ft}$ from the shot point, could not be de-watered by this technique.)

At 0800 on August 2, 1960, $946 \mathrm{lb}$ of nitromethane (plus 7 lb of Composition $B$ ) was fired in shot hole No. 1. There was no visible damage to the mine adit or to any structure associated with the workings. Only a minor ground shock and a small audible air wave were experienced by people at the observation point (4000 ft from the shot point). Reentry for sampling began two hours after zero time and samples were taken from all six holes during the next half hour. The procedure at each hole was as follows:

(1) The pressure in the hole was measured using a compound pressure gauge reading from $30 \mathrm{in.}$ of $\mathrm{Hg}$ vacuum to 100 psi gauge pressure.

(2) An evacuated bottle was attached to the sampling pipe and the valve on the pipe was opened to fill the bottle.

(3) The pressure in the bottle plus hole system was read, and the pipe valve closed. The maximum pressure observed in any hole was 10 psi gauge. Since the volume of the bottle was $1.2 \mathrm{cu} f$ and the volume of each sample hole about $1.1 \mathrm{cuft}$, the size of each sample was of the order of $0.5 \mathrm{cu} f \mathrm{ft}$ of gas at standard temperature and pressure. The gas pressure, sampling times, and sample volumes are given in Table II.

An extra sample was taken from hole 1.6 (range $125 \mathrm{ft}$ ) ten hours after the shot. This sample was flown to Livermore, along with the other postshot samples and a background sample obtained from hole 1.3 four days before the shot, in order that analysis could begin with a minimum of delay. A second series of 6 samples was taken from the same set of holes at +48 hours. At +72 hours a series of 6 samples from the holes drilled for the second shot (at distances of 180 to $340 \mathrm{ft}$ from shot hole No. 1) was also taken.

Samples were analyzed for $\mathrm{Kr}^{85}$ and, in addition, an aliquot of each sample was run on the mass spectrometer. The results are given in Table II. $\mathrm{Kr}^{85}$ was found in all samples taken at distances out to $125 \mathrm{ft}$, and none was detected beyond $125 \mathrm{ft}$. The $\mathrm{Kr}^{85}$ concentration in the samples out to $50 \mathrm{ft}$ appears to be more or less independent of space and time between +2 and +50 hours. Unfortunately, the sample at $75 \mathrm{ft}$ is not considered reliable, as the 
Table II. Chemical Analyses.

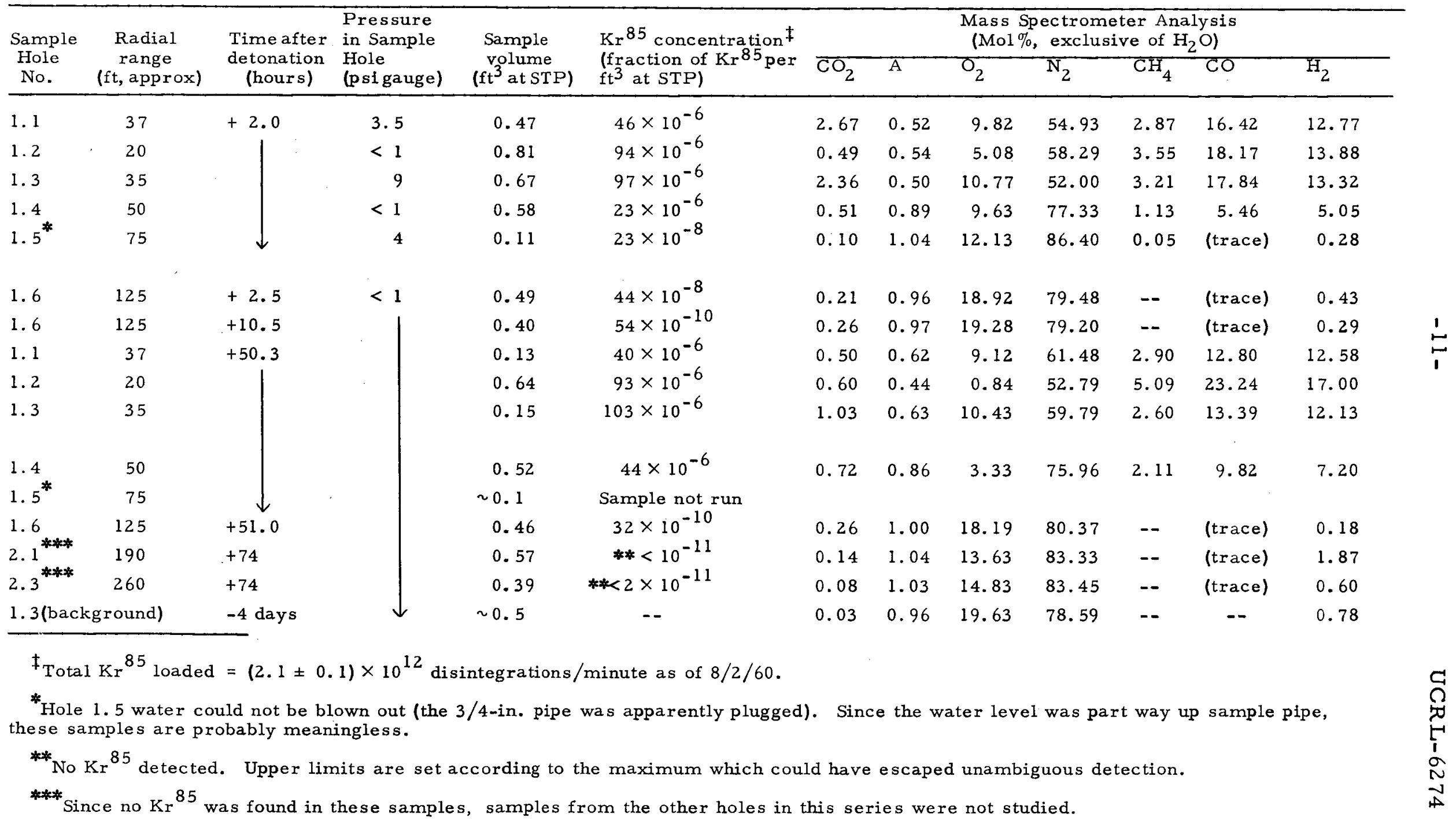


accumulated water could not be blown out of the gas sampling pipe. At $125 \mathrm{ft}$ the apparent $\mathrm{Kr}^{85}$ concentration was reduced from the close-in value by a factor of 100 at +2 hours and by a factor of 10,000 at +10 and +51 hours. It is not clear whether the +2 -hour sample from hole 1.6 is really representative of the gas at $125 \mathrm{ft}$ at 2 hours, or whether the sample was contaminated during the sampling process.

Venting of $\mathrm{Kr}^{85}$ into the adit after the shot was significant. Much of the gas apparently traveled through an almost vertical joint near the top of the hole. In addition, gas was found entering the adit from a newly formed crack in the grout plug. This crack was parallel to the joint just mentioned. About $(20 \pm 10) \%$ of the $\mathrm{Kr}^{85}$ escaped into the adit through these (and possibly other) cracks.

While it has been found possible to use the Pinot results for semiquantitative interpretation, as will be seen below, the experiment was designed basically for qualitative data. Therefore, when $\mathrm{Kr}^{85}$ was found in all of the holes associated with the first detonation it was decided to cancel the second (5000 lb) shot.

\section{RESULTS}

From a study of Table II, it appears that out to $50 \mathrm{ft}$, the concentration of both $\mathrm{Kr}^{85}$ and nitromethane decomposition products is (roughly) independent of both the horizontal distance to the shot point and the vertical distance from the shot point, although there is a suggestion that both $\mathrm{Kr}^{85}$ and combustion products are somewhat less concentrated at $50 \mathrm{ft}$. There is relatively little $\mathrm{Kr}^{85}$ or decomposition products at $125 \mathrm{ft}$. It is evident from the small changes in concentration with time that relatively little of the gas movement can be ascribed to a diffusion process. The only large change in concentration occurred at $125 \mathrm{ft}$ between +2.5 and +10.5 hours, and may not be real, as it was not accompanied by a corresponding change between +10.5 and +51 hours. One may therefore conclude from these observations that the force of the explosion distributed these products more or less uniformly throughout the medium to some distance between 50 and $125 \mathrm{ft}$ from the shot point. Shortly after the explosion, the gas occupied between $4 \%$ of the total volume out to $50 \mathrm{ft}$ and $1 / 4 \%$ of the volume out to $125 \mathrm{ft}$. 


\section{CONCLUSIONS}

The fact that there was significant horizontal underground communication in the oil shale was not recognized until a few days before the Pinot detonation. It is not believed, however, that the site chosen for Pinot was anomalous in this regard. * At the location of the experiment (about $500 \mathrm{ft}$ from the mesa slope), the vertical joints may be somewhat more open than they are deeper in the formation, but there is no reason to believe that the joint spacing at the shot site is particularly atypical. ${ }^{*}$ Therefore, it is reasonable to assume that the results of the Pinot experiment are more or less equally applicable to other locations in the Green River formation..

Since about $20 \%$ of the $\mathrm{Kr}{ }^{85}$ found its way into the adit from the shot point (125 ft below the adit floor), it would appear that the distance shot gases travel normal to the bedding planes is not very different from the distance they travel parallel to those planes. In other words, the evidence does not support the view that shot gases are propelled unusually long distances parallel to the bedding planes of the oil shale. On the contrary, the evidence is quite consistent with the hypothesis that the gases were distributed by the force of the explosion essentially uniformly per unit volume out to some distance of the order of $100 \mathrm{ft}$. This is true in spite of the horizontal connectivity of the medium. Therefore, either a similar degree of vertical connectivity exists at the Pinot site, or else the force of the explosion opens up the medium sufficiently (and relatively isotropically) to provide most of the passages for gas movement.

The results of the Pinot experiment cannot be extrapolated quantitatively to the case of a nuclear explosion in oil shale. Even if the structure at the Pinot site is typical of oil shale, the generation of a smaller quantity of noncondensable gases per unit energy in a nuclear explosion (as compared with a chemical explosion), the shorter time scale of the energy release, and the higher temperatures and pressures encountered will all have a definite influence on the effective containment distance. One can conclude, however, that, if the medium at the site of a potential nuclear experiment is similar to that at

* K. Stanfield, U.S. Bureau of Mines, private communication.

* J. R. Donnell, U.S. Geological Survey, private communication. 
Pinot, the radioactive gases will not travel preferentially in a direction parallel to the bedding planes, but rather will tend to expand more or less spherically from the shot point. In other words, an explosion in oil shale designed not to vent in a direction perpendicular to the bedding planes will be just as tight parallel to the bedding planes.

In order to understand the movement of these gases from a contained nuclear explosion in oil shale, further experiments will be required, especially with contained nuclear explosions in various media. 


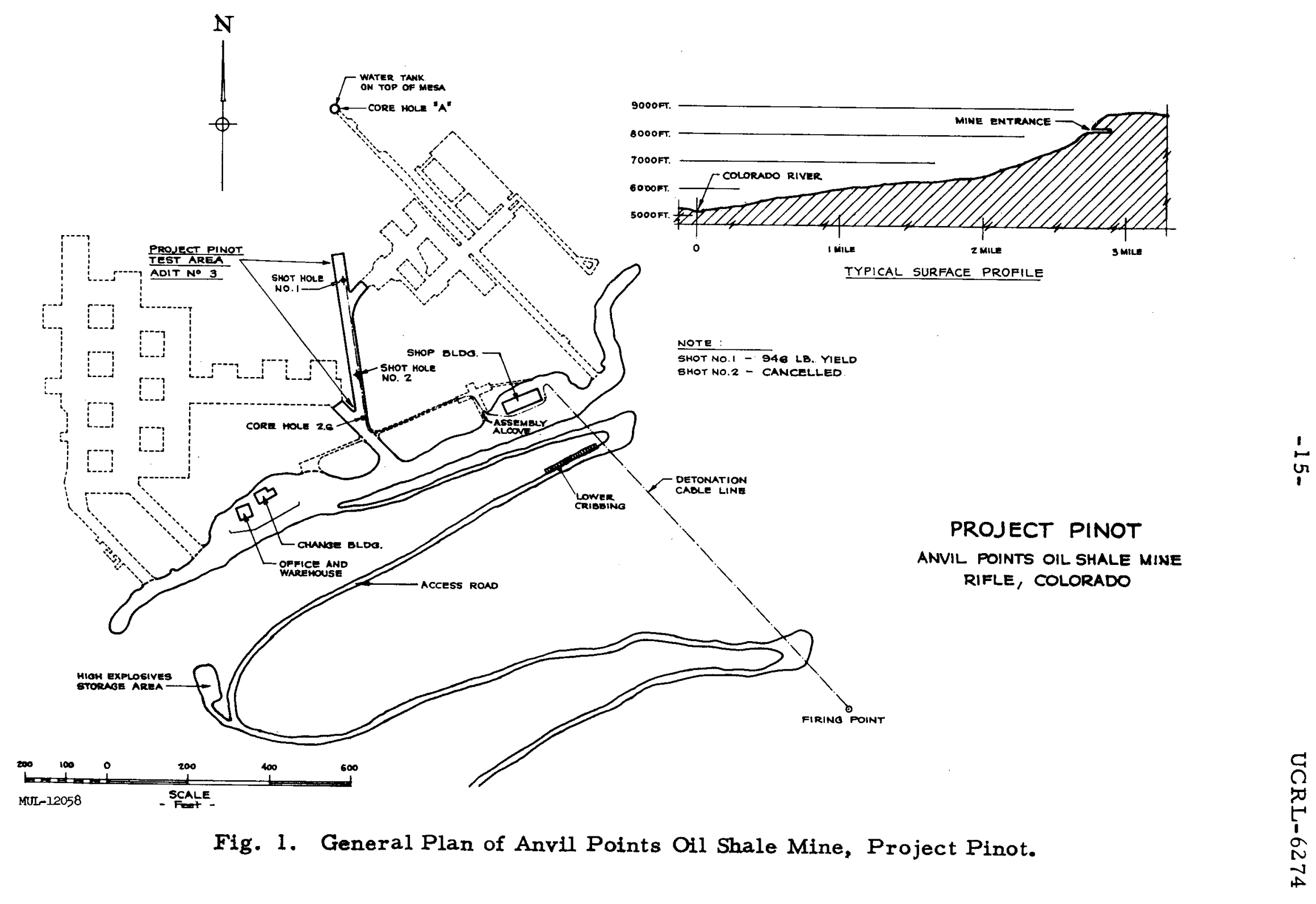



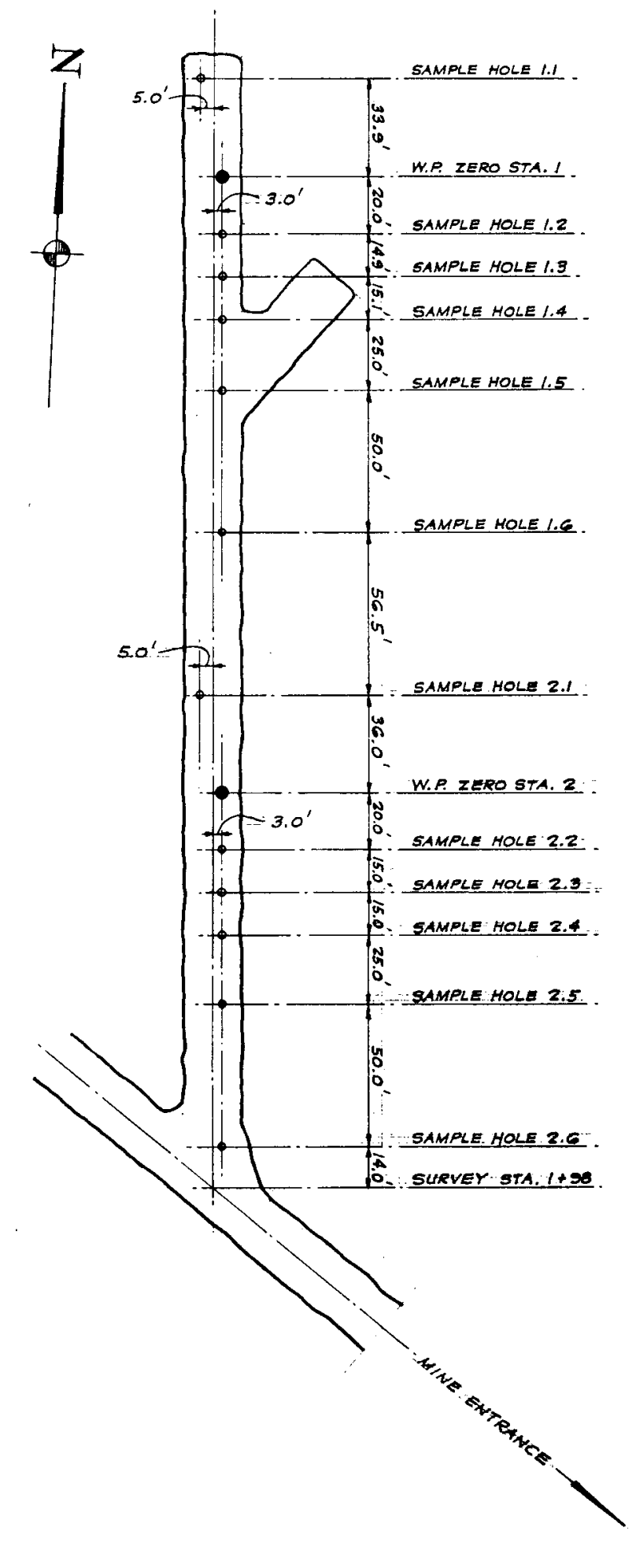

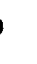

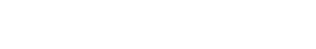

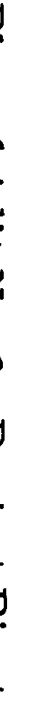

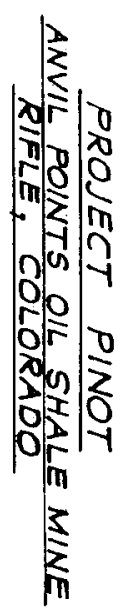




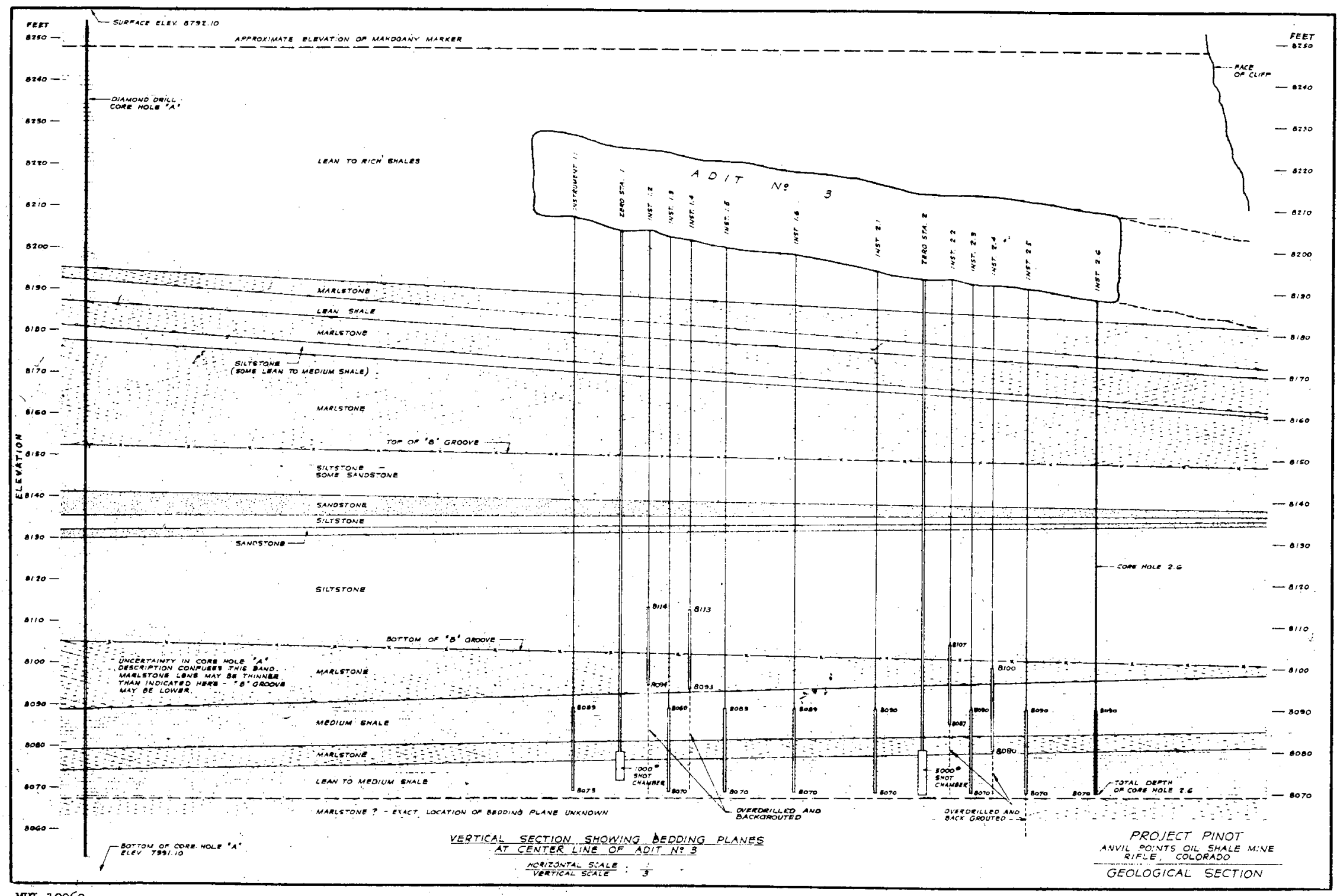

Fig. 3. Vertical Cross Section of Project Pinot. 


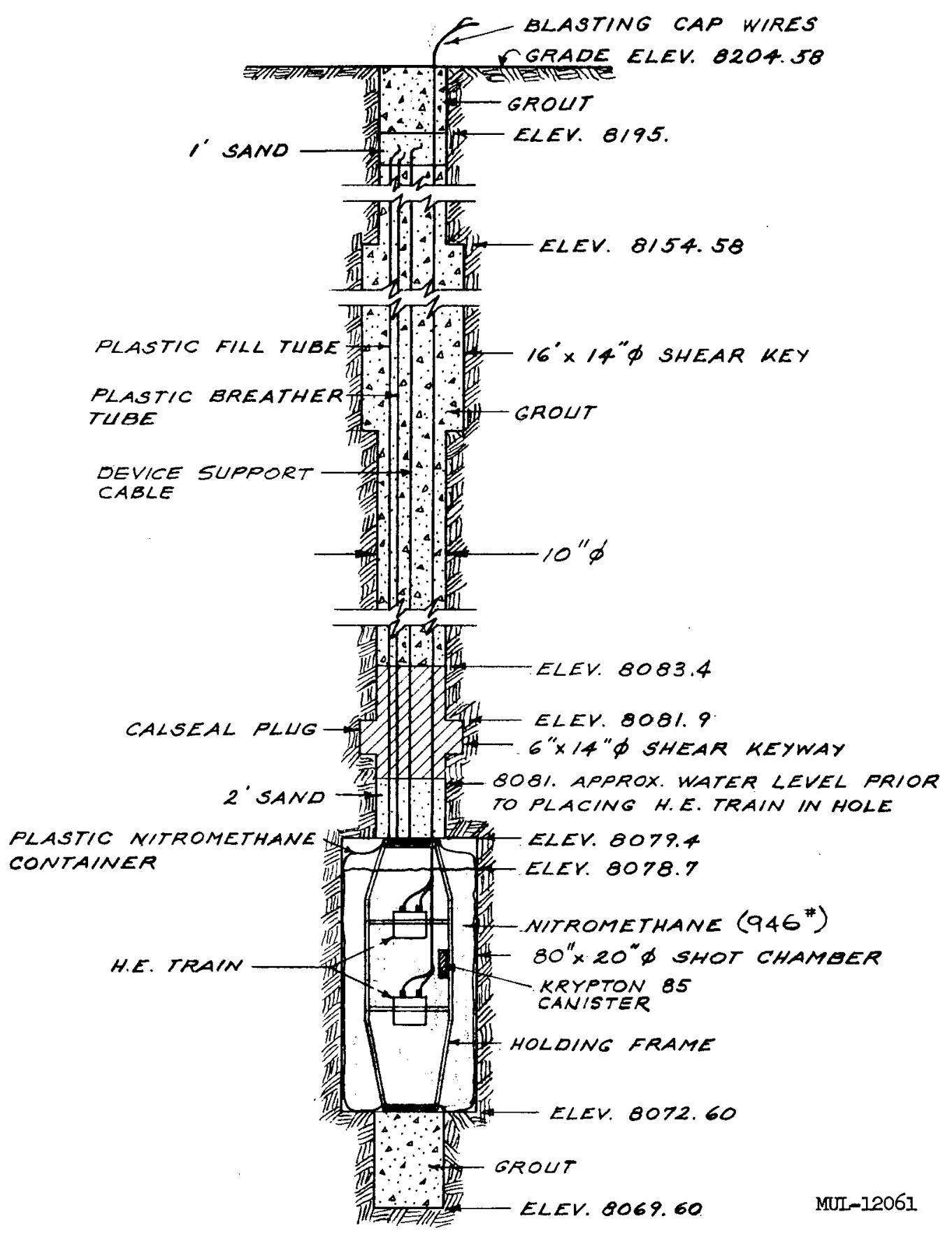

Fig. 4. Shot Hole No. 1 Detail, Project Pinot. 


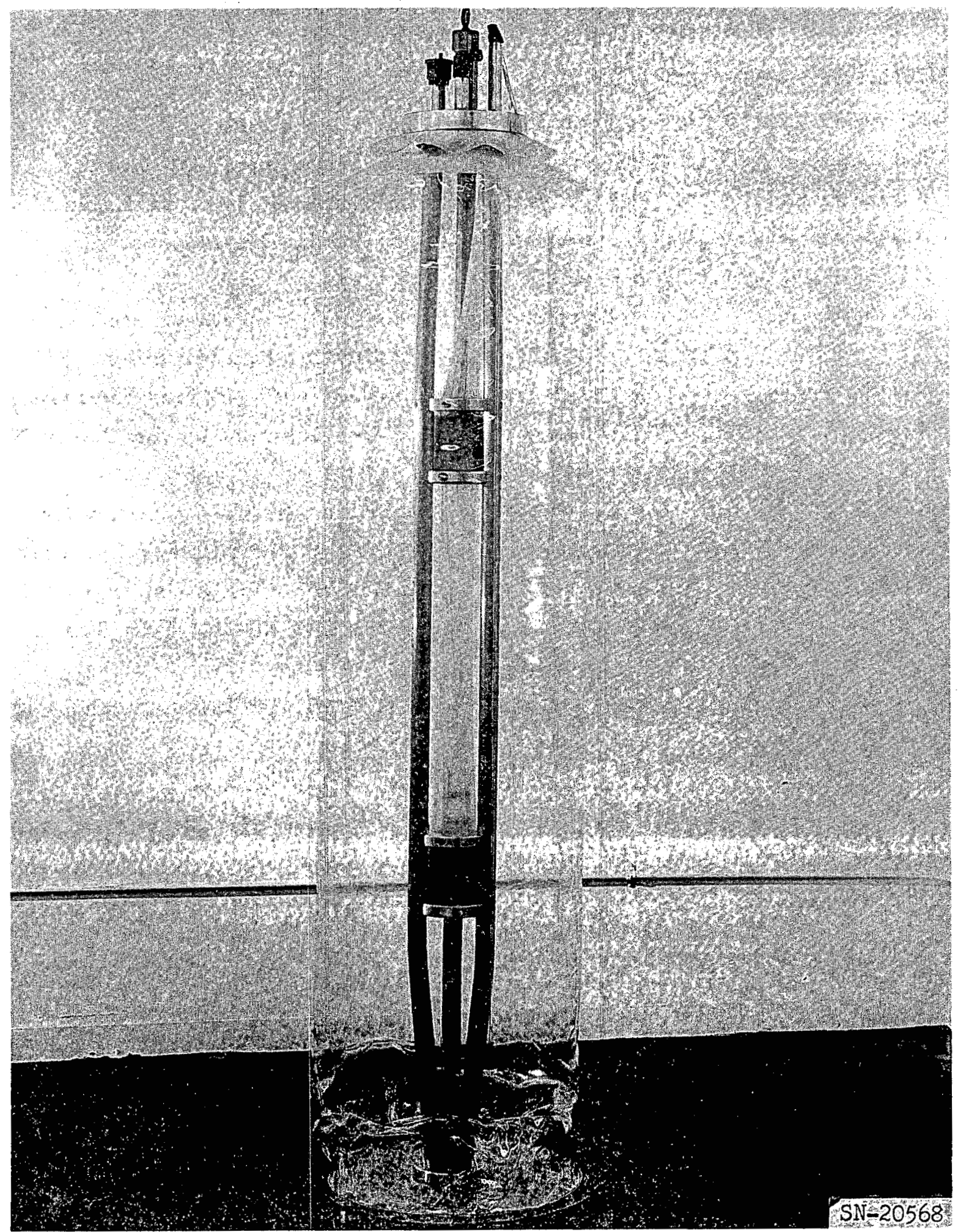

Fig. 5. Photo of 1000-lb Device for Shot Hole No. 1, Project Pinot. 


\section{LIST OF PREVIOUS PLOWSHARE AND/OR RELA TED REPORTS}

Report No.

UCR L- 4659

UCRL- 5026

UCRL-5124 Rev. I

UCR L- 5253

UCRL- 5257 Rev.

UCRL- 5281

UCR L- 5457

UCRL- 5458

UCRL- 5538

UCRL- 5542 Rev.

UCRL- 5623

UCRL- 5626

UCRL- 5709

UCRL- 5757

UCRL- 5766

UCRL- 5840

UCRL- 5882

UCR L-591 7

UCRL- 5928

UCRL-5932
Title

Deep Underground Test Shots.

Non-Military Uses of Nuclear Explosions.

Phenomenology of Contained Nuclear Explosions.

Industrial Uses of Nuclear Explosives.

Peaceful Use of Fusion.

Temperatures and Pressures Associated with the

Cavity Produced by the Rainier Event.

Large Scale Excavation with Nuclear Explosives.

Mineral Resource Development by the Use of Nuclear

Explosives.

Evaluation of the Ground Water Contamination

Hazard from Underground Nuclear Explosions.

Properties of the Environment of Underground

Nuclear Detonations at Nevada Test Site.

Rainier Event.

Radioactivity Associated with Underground Nuclear

Explosions.

Underground Nuclear Detonations.

Hydroclimatology and Surface Hydrology of San

Clemente Island.

Geologic Studies of Underground Nuclear Explosions

Rainier and Neptune.

The Neptune Event. A Nuclear Explosive Cratering

Experiment.

Industrial and Scientific Applications of Nuclear

Explosions.

Chemical Reactions Induced by Underground Nuclear Explosions.

Excavation With Nuclear Explosives.

Nuclear Explosives and Mining Costs.

The Soviet Program for Industrial Applications of

Explosions. 


\section{LIST OF PREVIOUS PLOWSHARE AND/OR RELATED REPORTS}

Report No.

UCR L- 5949

UCR L- 5968

UCRL-6013

UCR L-6030-T

UCRL -6054

UCRL- 6175

UCRL-6215

UCRL-6249-T

UCRL-6274

UCRL- 5675

UCR L- 5676

UCRL- 5677

UCRL- 5678

UCRL- 5679
Title

An Application of Nuclear Explosives to Block Caving Mining.

An In Vacuo Electromagnetic Dispersion Experiment.

Probing the Earth with Nuclear Explosions.

Application of Nuclear Explosions as Seismic Sources.

Fracturing of Rock Salt by a Contained High Explosive.

The System $\mathrm{H}_{2} \mathrm{O}-\mathrm{NaCl}$ at Elevated Temperatures and Pressures.

Can Peaceful Nuclear Explosions be Conducted Safely.

Distribution of Radioactivity from a Nuclear Excavation.

Final Report on the Pinot Experiment.

Plowshare Series: Report No.2. Proceedings of the Second Plowshare Symposium (Held at San Francisco, May 13-15, 1959):

Part I: Phenomenology of Underground Nuclear Explosions。

Part II: Excavation.

Part.III: Recovery of Power and Isotopes from Contained Underground Nuclear Explosions.

Part IV: Industrial Uses of Nuclear Explosives in the Fields of Water Resources, Mining, Chemical Production, and Petroleum Recovery.

Part V: Scientific Applications of Nuclear Explosives In the Fields of Nuclear Physics, Seismology, Meteorology and Space. 
This report was prepared as an account of Government sponsored work. Neither the United States, nor the Commission, nor any person acting on behalf of the Commission:

A. Makes any warranty or representation, expressed or implied, with respect to the accuracy, completeness, or usefulness of the information contained in this report, or that the use of any information, apparatus, method, or process disclosed in this report may not infringe privately owned rights; or

B. Assumes any liabilities with respect to the use of, or for damages resulting from the use of any information, apparatus, method or process disclosed in this report.

As used in the above, "person acting on behalf of the Commission " includes any employee or contractor of the commission, or employee of such contractor, to the extent that such employee or contractor of the Commission, or employee of such contractor prepares, disseminates, or provides access to, any information pursuant to his employment or contract with the Commission, or his employment with such contractor. 